\title{
ROZWÓJ INNOWACYJNOŚCI W ROSJI W XXI W.: ZADANIA I PERSPEKTYWY
}

ABSTRACT Innovative development of Russia in 21st century: tasks and perspectives The article examines the features of innovative development of Russia in the XXI century. It identifies a number of factors that influence the braking of the innovation process. For the 90 s of XX century the most important obstacles to innovation are, first of all, legal, technological and economic. Contemporary osbtalces are dominated by economic and technological factors. The author concludes that the issues that Russia faces today can be divided into two parts: the first set of problems is determined by the international situation, the second set is determined by trends of domestic development and is directly linked to the first one.

Keywords: innovations, innovation policy, innovative development, social and economic development, national interests

Słowa kluczowe: innowacje, polityka innowacyjna, rozwój innowacyjny, rozwój społeczny i polityczny, interesy narodowe 
$\mathrm{D}$ rugą połowę XX w. znamionuje przejście do świata postindustrialnego, którego efektem końcowym jest stworzenie „gospodarki opartej na wiedzy”. Głównymi czynnikami innowacyjnego typu rozwoju stają się informacja i wiedza. Nic więc dziwnego, że jako jeden z priorytetów polityki państwa większość krajów rozwiniętych obwieszcza przejście na innowacyjne tory rozwoju. Jednakże należy zauważyć, że na wcielenie w życie tego projektu wpływa ogromna liczba zarówno czynników obiektywnych, jak i subiektywnych. W tym kontekście aktualna staje się kwestia zbadania cech swoistych innowacyjnego rozwoju Rosji na obecnym etapie, jak również tendencji, zadań i perspektyw funkcjonowania „gospodarki opartej na wiedzy".

Cechą nowej fazy rozwoju innowacyjności jest przenikanie tendencji innowacyjnych do różnych sfer życia społecznego, co zmusza do badania procesu innowacyjności z różnych punktów widzenia i na jakościowo nowym poziomie. To pozwala badaczom zidentyfikować nowe cele, zadania i zasady funkcjonowania różnych aktorów. Trzeba uświadomić sobie, że wdrożenie innowacji to nie tylko problem techniczny czy ekonomiczny, chociaż właśnie w tych dziedzinach wiedzy naukowej zagadnieniom związanym z innowacjami udziela się najwięcej uwagi. Pod dyskusję poddawane są także kwestie związane $\mathrm{z}$ innowacjami w sferze zarządzania, sferze społecznej, politycznej etc., a także - zagadnienia filozoficznej refleksji nad rozwojem innowacyjności.

Budowaniu Narodowego Systemu Innowacji (NSI) towarzyszą co najmniej dwa procesy uzupełniające na poziomie państwowym, co ostatecznie wpływa i na sam proces polityczny. $\mathrm{Z}$ jednej strony realizacja polityki innowacyjnej to urzeczywistnienie interesów narodowych, z drugiej - wszystkie sfery życia społecznego w ten czy inny sposób uwzględniają składową innowacyjności: w sferze gospodarczej - wzrost innowacyjnej produkcji; w sferze społecznej - zapewnienie jakości kapitału ludzkiego (poprawa jakości usług medycznych, edukacji etc.); w sferze politycznej - aktywne uczestnictwo obywateli w życiu politycznym, społeczna kontrola realizacji pewnych decyzji itp.; w sferze ekologii - poszukiwanie nowych zasad interakcji ze środowiskiem naturalnym; w polityce zagranicznej - integracja z globalnym kompleksem innowacji. Wpływ na proces polityczny wynika $\mathrm{z}$ faktu, że jednym z warunków skutecznego funkcjonowania NSI jest tworzenie innowacyjnych wartości, które ostatecznie powinny być przyjęte przez całe społeczeństwo.

Biorąc pod uwagę wielokrotne deklaracje przywódców kraju na temat konieczności budowy narodowego systemu innowacji, celowe wydaje się określenie czynników i ryzyka, które utrudniają działalność innowacyjną.

W procesie implementacji działań innowacyjnych należy wziąć pod uwagę czynniki, które mają wpływ na hamowanie procesu innowacyjności. Możemy wyróżnić następujące grupy czynników, które mogą w jakiś sposób utrudniać działalność innowacyjną różnych podmiotów:

- Czynniki ekonomiczne. Do tej grupy zaliczane są przede wszystkim te okoliczności, które mogą hamować finansowanie badań i projektów naukowych, reali- 
zację projektów innowacyjnych. Na przykład brak wewnętrznych aktywów finansowych przedsiębiorstwa; brak lub niewystarczające finansowanie ze źródeł zewnętrznych; niezdefiniowany popyt na innowacje; długi okres zwrotu nakładów na innowacje; niewystarczający potencjał innowacyjności itd.

- Czynniki technologiczne - związane z brakiem odpowiedniej bazy materialnej niezbędnej do wdrażania innowacji.

- Czynniki prawne. Prawne aspekty wsparcia innowacyjności działają poprzez tworzenie konkretnych ram instytucjonalnych dla funkcjonowania podmiotów procesu innowacji. Jako przykład można wymienić ograniczenia ze strony różnych gałęzi prawa - podatkowego, antymonopolowego; ograniczenia w zakresie przyznawania patentów i licencji.

- Czynniki polityczne - brak woli politycznej w rozwiązywaniu różnego rodzaju problemów.

- Czynniki zwiazane z zarządzaniem. Do czynników związanych z zarządzeniem zaliczają się skutki uboczne nieefektywnego zarządzania. Przykładem może być orientacja tylko na realizację planów krótkoterminowych, częsta nadmierna centralizacja procesu decyzyjnego; brak związków sieciowych i jako konsekwencja - brak interakcji poziomych; przy podejmowaniu decyzji - brak korelacji celów i zadań oraz sposobów ich realizacji. Te oraz wiele innych okoliczności oznaczają, że jakość zarządzania jest niska, a kierowanie można scharakteryzować jako nieefektywne.

- Czynniki socjokulturowe, związane ze swoistością rozwoju historycznego i kulturowego społeczeństwa. Ze względu na utrwalone stereotypy i ukształtowaną tradycję wdrażane innowacje mogą spotykać się z przejawami braku akceptacji społecznej.

Analizując rosyjską rzeczywistość, autorka dochodzi do wniosku, że w latach 90. XX w. najważniejszymi czynnikami stojącymi na przeszkodzie implementacji innowacji były przede wszystkim czynniki prawne, technologiczne i ekonomiczne. Obecnie są to czynniki ekonomiczne i technologiczne. W procesie podejmowania decyzji związanych z zarządzaniem należy jednak brać pod uwagę cały kompleks czynników.

Realia współczesnego świata stawiają przed Rosją szereg kwestii, które wymagają podjęcia konkretnych decyzji. Zbiór tych zagadnień można podzielić na dwa bloki. Pierwszy kompleks problemów zdeterminowany jest przez sytuację na arenie międzynarodowej oraz swoiste cechy polityki światowej na obecnym etapie rozwoju.

Wiele państw świata $\mathrm{w}$ różnym stopniu zbliżyło się do progu przejścia do stadium rozwoju innowacyjnego. Różni autorzy porównują ten proces do rewolucji przemysłowej w XVIII w. oraz do rewolucji naukowo-technicznej w XX w. Efektywność bądź nieefektywność jest określana przez obecność doskonałych wskaźników rozwoju gospodarczego i społecznego. Co więcej, w warunkach silnej konkurencji międzynarodowej rywalizacja z innymi państwami zapewnia dodatkowy impuls dla rozwoju sfery innowacyjności. Badacze ustalili nawet związek między konkurencją i wzrostem gospodarczym: jeśli zmiany gospodarcze zagrażają przywództwu politycznemu państwa, to obecność konkurujących państw może sprzyjać innowacjom. Wnioskiem z tego jest fakt, że 
duże państwa, nie mając znaczacych konkurentów, przestaja być żyzna gleba dla trwatego wzrostu gospodarczego ${ }^{1}$.

Tak więc podtrzymując status mocarstwa, odgrywającego znaczącą rolę na arenie międzynarodowej, Rosja powinna za kierunek priorytetowy uznać rozwój innowacyjności.

Drugi kompleks problemów, zdeterminowany przez kierunki rozwoju wewnętrznego kraju, jest bezpośrednio związany z pierwszą grupą problemów. Innowacyjne społeczeństwo zakłada zmianę relacji między jednostką i społeczeństwem, między społeczeństwem i państwem. Zdając sobie sprawę z konieczności zmian politycznych, kierownictwo kraju stopniowo podejmuje odpowiednie kroki. Tę konieczność uświadamia sobie także społeczeństwo. Podejmowane decyzje powinny jednak być oparte nie tylko na chęci uzyskania oczekiwanego rezultatu, ale także na adekwatnej wiedzy o sytuacji wyjściowej i możliwych konsekwencjach decyzji zarzadczych ${ }^{2}$. Jednak pozyskanie wiedzy o rzeczywistej sytuacji możliwe jest w procesie interakcji między społeczeństwem a państwem. Innymi słowy - jeśli istnieje sprzężenie zwrotne.

Budowanie „pionowej struktury władzy”, uwarunkowane wymogiem czasu, stopniowo przekształca się w sprawowanie władzy przez dość zamkniętą grupę ludzi. Początkowa efektywność „pionowej struktury władzy” z czasem traci swoje pozytywne cechy i nabiera charakteru stagnacji. W takich warunkach "pionowa struktura władzy” powinna zostać zmodernizowana na poziomie instytucjonalnym, co oznacza dopełnienie jej strukturą poziomą.

Biurokracja jako niezbędny element administracji publicznej powinna również zostać poddana modernizacji. Rozpatrywane w pierwszej części niniejszego artykułu czynniki innowacyjnego zarządzania zakładają m.in. orientację na rezultaty, a nie na proces ich uzyskania, akcentowane jest osiąganie jak największych rezultatów społecznych przy jak najniższych kosztach. Podczas zmiany struktury biurokratycznej ważne miejsce zajmuje wdrażanie zasad e-administracji, które obecnie stopniowo zaczynają być wykorzystywane w różnych urzędach. Środki te również częściowo rozwiązują problem z dostępem do informacji zwrotnej od społeczeństwa.

$\mathrm{Z}$ naszego punktu widzenia trudności w przejściu Rosji na innowacyjne ścieżki rozwoju związane są z szeregiem problemów, które można umownie podzielić na kilka grup, eksponujących ekonomiczne i polityczne aspekty reform w sferze innowacji, wsparcie legislacyjne, społeczno-kulturową swoistość Rosji.

Powszechnie uznawany jest wystarczająco wysoki potencjał naukowo-techniczny państwa. Jednak w praktyce nie jest on w znacznym stopniu zaangażowany w trwającą transformację gospodarki. Jak zaznaczono w „Strategii rozwoju innowacyjnego Federacji Rosyjskiej na okres do roku 2020” („Стратегия инновационного развития Российской Федерации на период до 2020 года"), kluczowym problemem jest fakt, że dominuje ogólnie niski popyt na innowacje w gospodarce rosyjskiej i nieefektywna struk-

A. Chaudhry, P. Garner, Political Competition between Countries and Economic Growth, „Review of Development Economics" 2006, Vol. 10, nr 4, s. 678.

2 Модернизачия и политика в XXI веке, red. Ю. Оганисьян, Москва 2011, s. 4. 
tura tego popytu, z uwagi na fakt, że często państwu i sektorowi prywatnemu łatwiej kupić gotowy produkt lub sprzęt za granicą, aniżeli finansować własne opracowania i wdrażać je do produkcji. Niska podatność struktur biznesowych na innowacyjność technologiczną stwarza bariery dla rozwoju sektora produkcyjnego ${ }^{3}$.

Innowacyjny rozwój Rosji wymaga dziś kompleksowego podejścia do zmian systemowych. W dokumentach programowych główny nacisk kładziony jest na kwestie ekonomiczne. Jednak, naszym zdaniem, perspektywy rozwoju innowacyjnego Rosji związane są m.in. ze strategia innowacyjnego rozwoju kraju, oparta na jednym z gtównych atutów konkurencyjności - na uwzględnieniu potencjatu ludzkiego ${ }^{4}$. Często jednak widzimy, że finansowanie rozwoju edukacji, medycyny, sfery społecznej jako takiej nie jest prowadzone na odpowiednim poziomie: udział kapitału ludzkiego i kapitału społecznego w majątku narodowym Rosji szacuje się na około 25-50\% (reszta to zasoby naturalne i aktywa produkcyjne); w krajach rozwiniętych udział kapitału ludzkiego i społecznego wynosi $70-75 \% 5$.

Ważną rolę w tym procesie odgrywają oczywiście takie czynniki, jak rozszerzenie dialogu między państwem a społeczeństwem, wyraźna instytucjonalizacja innowacji, polityka zorientowana społecznie, efektywne wykorzystanie wszystkich rodzajów zasobów. Często brak ukształtowanego dojrzałego społeczeństwa obywatelskiego, działających mechanizmów sprzężenia zwrotnego, dobrze funkcjonującego systemu politycznego doprowadza do różnych problemów w interakcji pomiędzy państwem a społeczeństwem, do utrudnienia procesu podejmowania decyzji politycznych itp.

Konsekwencją powyższego jest także konieczność aktywizacji i wykorzystania zasobów społecznych, maksymalnego upodmiotowienia procesów innowacyjno-modernizacyjnych. Oznacza to, że w roli czynników sprawczych modernizacji powinno występować nie tylko państwo, lecz także sektor biznesowy i środowisko naukowe - innymi słowy, narodowy system innowacji, zakładający wzajemną i dopełniającą się współpracę różnych podmiotów modernizacji.

Programy, strategie, koncepcje są przede wszystkim konceptualną podstawą rozwoju innowacyjnego. Tego rodzaju dokumenty są tylko pewnym punktem odniesienia w polityce prowadzonej przez państwo. Cele zakładane w dokumentach programowych i koncepcyjnych, zadania i zasady realizacji różnych przedsięwzięć w istocie nie są obligatoryjne, raczej mają charakter rekomendacji, w odróżnieniu od regulacji, których niewypełnienie pociąga za sobą bezpośrednie sankcje prawne. W związku z tym konieczne jest przyjęcie pakietu ustaw federalnych, które sankcjonujących jasno określone działania urzeczywistniające przejście Rosji do stadium rozwoju innowacyjnego.

3 Na przykład w 2009 r. opracowanie i wdrożenie innowacji technicznych przeprowadziło 9,4\% ogólnej liczby przedsiębiorstw przemysłowych w Rosji. Dla porównania w Niemczech - 71,8\%, w Belgii 53,6\%, w Estonii - 52,8\%, w Finlandii - 52,5\%, w Szwecji - 49,6\%.

4 Выступление Президента Российской Федерации В. В. Путина на расширенном заседании Государственного совета „О стратегии развития России до 2020 года”, 8 II 2008, [online] http:// archive.kremlin.ru/text/appears/2008/02/159528.shtml, 30 VI 2015.

5 Инновационная модернизация России. Политологические очерки, red. Ю. Красин, Москва 2011, s. $18-19$. 
Ważną rolę w przyjmowaniu takich ustaw powinna odgrywać współpraca między władzą, środowiskiem naukowym i biznesem.

Warto również zauważyć, że najważniejszym czynnikiem zapewniającym konkurencyjność społeczeństwa na arenie międzynarodowej jest rozwój gospodarki innowacyjnej. Już samo postawienie tej kwestii $w$ paradoksalny sposób świadczy o tym, że pojawienie się $i$ adaptacja innowacji nie jest wytacznie problemem ekonomicznym ${ }^{6}$. Jak wspomniano wyżej, innowacje to szeroki zakres przemian, wykraczających poza ramy zmian czysto technicznych. W tym kontekście innowacje w sferze techniki nie są możliwe bez fundamentalnej przemiany w konceptualnym postrzeganiu otaczajacego świa$t a^{7}$. Przy czym na przyjęcie lub odrzucenie innowacji wpływa zarówno środowisko instytucjonalne i kultura polityczna, jak i poziom rozwoju kapitału ludzkiego oraz stopień dostępu do już istniejącej wiedzy. Często mamy w tej materii do czynienia ze swoistością rzeczywistości społeczno-kulturowej, których po prostu nie można nie brać pod uwagę.

Jest jasne, że dla całego kraju perspektywa i kierunek rozwoju innowacyjnego nie mają alternatywy. Przed państwem staje bardzo trudne zadanie - urzeczywistnienie prawidłowej polityki w tej dziedzinie. Problem umownie można podzielić na dwa zadania:

1) wypracowanie wspólnej polityki państwa w zakresie rozwoju innowacji we wszystkich sferach życia społecznego;

2) realizacja i wsparcie odpowiedniej jakości polityki państwa w tym zakresie.

Pierwsze zadanie bezpośrednio wiąże się ze zrozumieniem charakteru rozwoju różnych dziedzin: sfery gospodarczej, społecznej, rozwoju duchowego, systemu politycznego itd. Głównym czynnikiem rozwoju ogólnej polityki państwa jest systemowość opracowywanych rozwiązań. Należy także zauważyć fakt, że powinna mieć miejsce racjonalna ocena i wypracowanie odpowiednich rekomendacji dokonywanych na podstawach naukowych. Nieocenioną rolę może tu odegrać politologia.

Wykonanie drugiego zadania jest bezpośrednio związane z jakością realizacji pierwszego i przede wszystkim z jakością decyzji dotyczących reformy systemu politycznego. Oficjalne oświadczenia najwyższego kierownictwa kraju z końca 2011 r. świadczą o uświadomieniu sobie konieczności systemowych zmian politycznych. Warto zauważyć, że jednym z „wąskich gardeł” współczesnej rosyjskiej polityki innowacyjności jest brak monitoringu i dokładnej oceny przyjętych strategii, programów i konkretnych rozwiązań ${ }^{8}$.

Zdaniem autorki niniejszego artykułu ważnym mechanizmem w budowaniu narodowego systemu innowacyjnego jest przesunięcie akcentu na regionalną politykę innowacyjności, jak również na opracowanie specjalnej ustawy regulującej regionalną politykę naukowo-techniczną, która pomoże skorygować ogólnopaństwowy kierunek

6 В. Сергеев, Инновачии как политическая проблема, „Полития” 2008, nr 1 (48), s. 114.

7 Tamże.

8 Н. Иванова, Бумажныци тигр (о проекте МЭР „Инновачионная Россия - 2020”), „Инновации” 2011, nr 2 (48), s. 3. 
rozwoju innowacyjności. W ramach narodowego systemu innowacji region jest jednym z głównych aktorów, którego specjalizację będzie określać obecność wymaganej liczby odpowiednich zasobów. Wzmocnienie regionalnej polityki innowacji może zostać przeprowadzone na różne sposoby: za pomocą celowych programów federalnych, wyłanianych w konkursach projektów innowacyjnych, gospodarczej stymulacji działalności innowacyjnej etc.

Ponadto, autorka uważa, że innym, efektywnym mechanizmem wzmocnienia aktywności innowacyjnej jest bardziej racjonalne i skorelowane z systemem podatkowym stymulowanie, które powinno obejmować wszystkie podmioty działalności innowacyjnej.

W związku z tym możemy wnioskować, że ramy prawne regulujące rozwój innowacyjności są stopniowo tworzone. Rozwiązaniu tej kwestii szczególną uwagę poświęca państwo. Jednak nie należy zapominać, że istnieje szereg problemów zarówno natury obiektywnej, jak i subiektywnej. Wskazane wyżej kwestie rzeczywiście utrudniają przejście kraju na innowacyjne tory rozwoju. Zdaniem autorki kluczem do rozwiązania tych problemów jest opracowanie systemu polityki państwa w dziedzinie rozwoju innowacyjnego, jego konceptualna interpretacja i kontrola nad jakością procesu decyzyjnego.

Tłumaczenie: Magdalena Romanowska

\section{BIBLIOGRAFIA}

Выступление Президента Российской Федерачии В. В. Путина на расииренном заседании Государственного совета „О стратегии развития России до 2020 года”, 8 II 2008, [online] http://archive.kremlin.ru/text/appears/2008/02/159528.shtml.

Иванова Н. И., Бумажный тигр (о проекте МЭР „Инноващионная Россия - 2020”), „Инновации” 2011, nr 2 (48).

Инновачионная модернизачия России. Политологические очерки, red. Ю. А. Красин, Москва 2011.

Модернизация и политика в XXI веке, red. Ю. С. Оганисьян, Москва 2011.

Сергеев В. М., Инновачии как политическал проблема, „Помития” 2008, $\operatorname{nr} 1$ (48).

Chaudhry A., Garner P., Political competition between countries and economic growth, „Review of Development Economics" 2006, nr 10 (4).

Jekatierina Giennadiewna KIRSANOWA - doktor nauk politycznych, asystent w Katedrze Polityki Rosyjskiej na Wydziale Politologii Moskiewskiego Uniwersytetu Państwowego im. M. Łomonosowa. 